\title{
Experimental Evaluation of the Employment of a Laminated Composite Material with Sisal Fibres as Reinforcement in Timber Beams
}

\author{
Samuel Sander Carvalho, Je zrael Rossetti Dutra, André Cerávolo de Carvalho, \\ Luciano Machado Gomes Vieira, André Luis Chris toforo*
}

Department of Mechanical Engineering, Federal Univ ersity of São João del-Rei, 36.307-352, Brazil

\begin{abstract}
Timber is the oldest construction materials in the world, have been widely used in structures in addition to having a high longevity, if treated properly (maintenance). If this does not occur, the wood deteriorates due to the action of insects, fungi and other aggressive agents. There are several materials and techniques used to reinforce the damaged parts. This paper presents an experimental study ofEucalyptus grandis and Pinus elliiottiitimber beams rein forced with sisal fibres laminated composite materials. The composite material and the wood were prepared for testing. In order to simulate the defect, some parts were cracked. The study was to determine the maximum load (rupture) applied on the timberin the conditions: without defect, with defect and without composite and with defect and with composite, aiming to verify the efficiency of the laminate as reinforcement in the wooden beams. The experimental results indicate the possible use of the laminated composite as reinforcement, presenting considerable increase in the maximum strength supported by the timber when compared to unreinforced cracked condition, being more efficient for the Pinus elliiottii species.
\end{abstract}

\section{Keywords Laminate Composite, Sisal Fibre, Timber Beams, Structural Reinforcement}

\section{Introduction}

Beams are structural elements present in most of buildings. Among the usual materials engineering highlights the wood, to be from natural and renewable source, low density and good mechanical performance. Timber structures when not treated properly can present problems due to the attack of biological degrading agents that contribute to the loss of their physical and mechanical properties, compromising the integrity of the structural components.

The study of repair and reinforcement in the structure of wood has been the focus of technical and scientific papers, aimed at developing viable solutions to be used in the recovery of the same[1-7].

Of the possible materials used as reinforcement and repair wooden structures stand out from the composites, because it is a material designed, in order to obtain a resultant mechanical properties superior to those of constituent phases [8].

The use of vegetable fibres such as sisal [9-14], co ir, jute, bananaand bamboo as reinforcement in la minates composite are considered as a good solution, show good tensile

* Corresponding author:

alchristo foro@y ahoo.com.br (André Luis Christoforo)

Published online at http://journal.sapub.org/cmaterials

Copyright (C) 2012 Scientific \& Academic Publishing. All Rights Reserved strength[15-18], and are materials biodegradable and of low cost when compared to synthetic fibres [19].

With the purpose of developing alternatives as reinforcement in beams, this paper aims at the development and characterization of composite laminated polymer matrix reinforced with sisal fibres to be used as reinforcement in Eucalyptus grandis and Pinus elliottii timber beams. The wooden beams with and without the use of the composite laminate is tested in bending, by making use of the static three point bending tests, and comparing the maximum strengths condition to the faultless timber, and defective unreinforced and re inforced, and faulty, making it possible to evaluate the efficiency of the manufacture composite.

\section{Material and Methods}

The raw material used is a vegetable fiber and sisal as reinforcement and resin epoxy as matrix fase. The laminate composite was manufacture with a layer. The fiber used was obtained fro mthe Sisal co mpany (Brazil), with caution as the use of fibres from the same batch. The Pinus elliottii and Eucalyptus grandis timber used in the fabrication of the specimens was obtained in a local sawmill in São João del-Rei (MG-Brazil), having as a precautionary pre-screeni ng of samples free defects.

Brackets have been manufactured of cast iron with 225 $\mathrm{mm}$ by $160 \mathrm{~mm}$ wide synthetic enamel coated. The sisal 
fibers were woven in a direction perpendicular to the length of the square, so as to stay closer to each other (Figure 1), and with tension on the nodes from the seams positioned on the metal rods, not allowing the presence of nodes in the structure of the laminate.

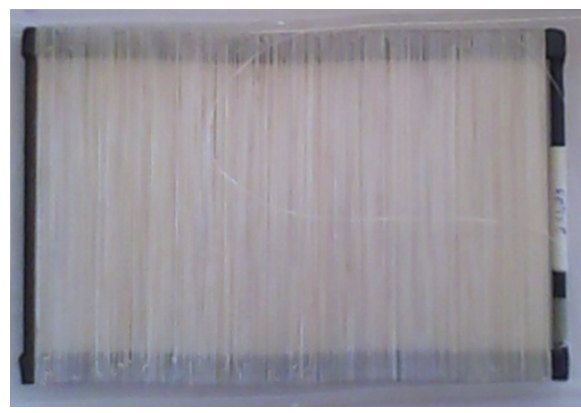

Figure 1. Woven of sisal fibres

To elaborate the composite material, the volume of the fibre should correspond to thirty precents of the total[8], and the remaining seventy percents should correspond to the volume of resin. From these data the total weight of resin to be applied in the composite was then calculated.

$60 \mathrm{~cm}$

(a)

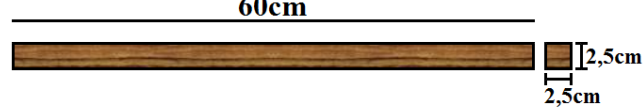

(b)

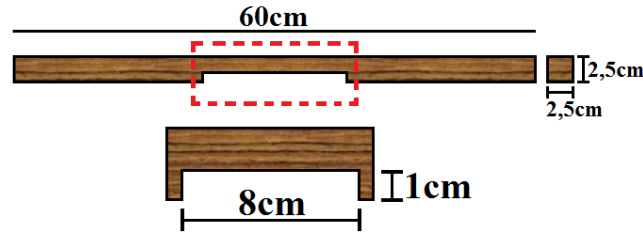

Figure 2. Dimensions of the specimens: (a) Flawless; (b) defective

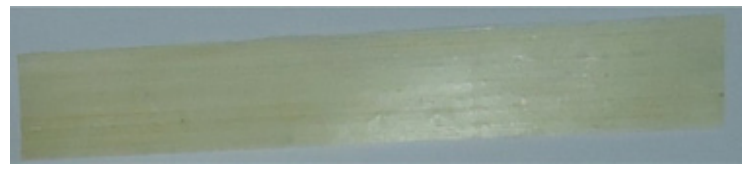

(a)

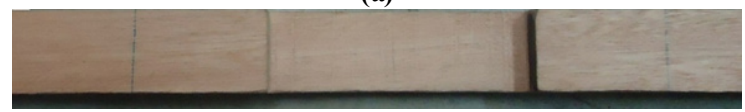

(b)

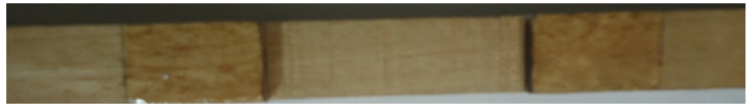

(c)

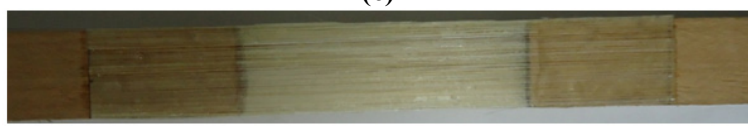

(d)

Figure 3. (a) Laminate sisal; (b) Flawless timber; (c) Bonding area; (d) Composite fixed on timber

Eight specimens of timber, four of each species, were made by sawing them pris matic shape with square cross section with dimensions $60 \times 2.5 \times 2.5 \mathrm{~cm}$ (Figure 2). Four of these (two of each species) were damagein the centre of their bases, measuring $8 \times 2.5 \times 1 \mathrm{~cm}$ (Figures $3 \mathrm{~b}$ and $3 \mathrm{c}$ ). Finally, two of the specimen defective (one for each species) have been reinforced with the laminate (Figure 3a) and its adhesion was performed by use of the resin while maintaining a bonding with $10 \mathrm{~cm}^{2}$ of area of each side groove (Figure 2c) and curing by seven days. For adhesion of the laminate to the timber (Figure 3d) was used in the same proportions resin used to manufacture the composite.

The mechanical bending tests were performed in an EMIC testing machine with loading speed of $1 \mathrm{~mm} / \mathrm{min}$. The modulus of elasticity $\left(E_{m}\right)$ and strength fle xural modulus $\left(f_{m}\right)$ of the specimenswithout defect (no failure) was obtained according to the Brazilian standard NBR 7190[13], respectively expressed by Equations 1 and 2, $F_{10 \%}$ and $F_{50 \%}$ and $10 \%$ and $50 \%$ of maximum load $\left(F_{\max }\right), L$ is the length of the useful parts (distance between supports) and $b$ and $h$ the width and height measures of the cross section respectively.

$$
\begin{gathered}
E_{m}=\frac{\left(F_{50 \%}-F_{10 \%}\right) \cdot L^{3}}{4 \cdot\left(\delta_{50 \%}-\delta_{10 \%}\right) \cdot b \cdot h^{3}} \\
f_{m}=\frac{3 \cdot F_{\max } \cdot L}{2 \cdot b \cdot h^{2}}
\end{gathered}
$$

The dimensions of the specimens following the $L \geq 21 \cdot h$ relation, neglecting the effect of shear forces in the calculus of the displacements[20-22].

\section{Results andDiscussions}

Os testes realizados com as madeiras íntegras geraram fraturas frágeis (Figura 4a) e também por propagação de trincas (Figuras $4 \mathrm{~b}, 4 \mathrm{c}$ e $4 \mathrm{~d}$ ).

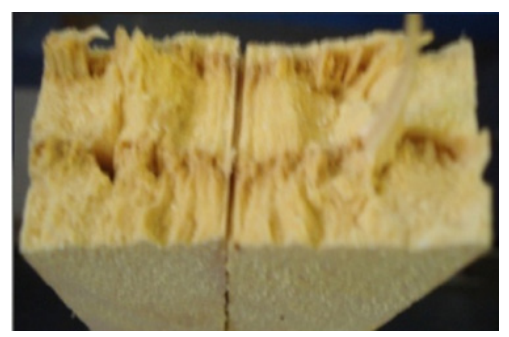

(a)

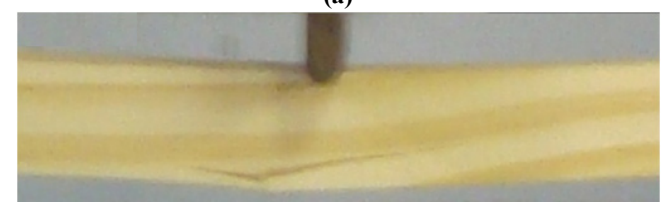

(b)

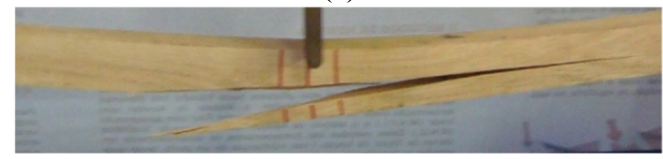

(c)

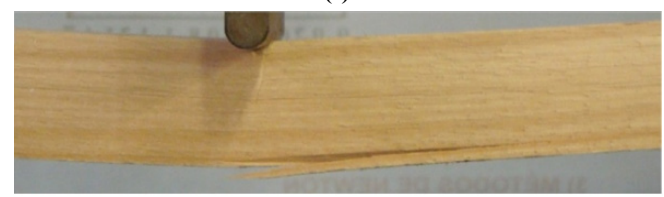

(d)

Figure 4. Fractures in timber due to the imposition of load on the bending test. (a) Fragile Fracture - Pinus elliiottii; (b) Fracture by crack propagat ion - Pinus elliiottii; (c) and (d) Fracture by crack propagation - Eucalyptus grandis 
The tests performed with the wood cracked generated crack propagation precisely in points where there stress concentrators, as shown in Figure 5.

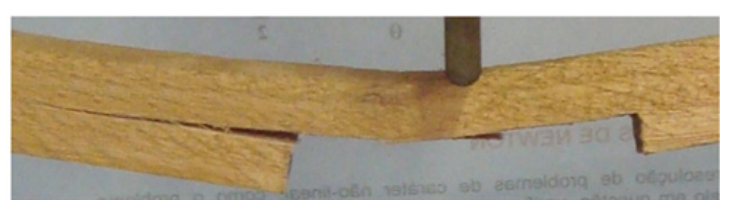

(a)

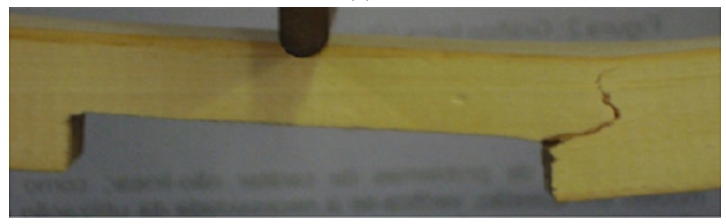

(b)

Figure 5. Fractures in the woods cracked by the imposition of load on the bending test. Fracture by crack propagation in a region of stress concentration: (a) Eucalyptus grandis and (b) Pinus elliiottii

Finally, tests carried out with the additional have differentfailure mechanisms. While in the Pinus was disruption of the composite material (Figure 6), there was a break in Eucalyptusspecies, which has subsequently damage the composite material (Figure 7).

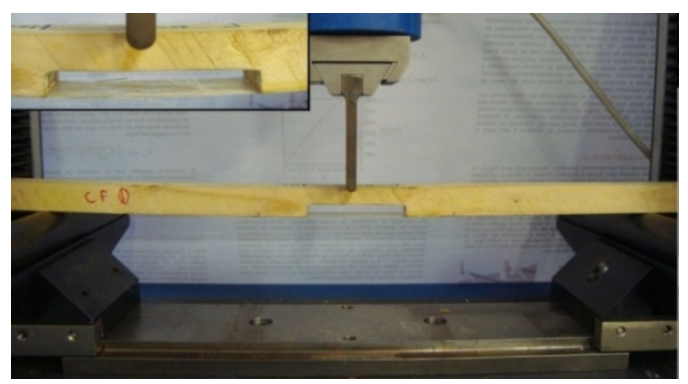

Figure 6. Specimen of Pinus intact with rupture of the composite material in bending test (left top)

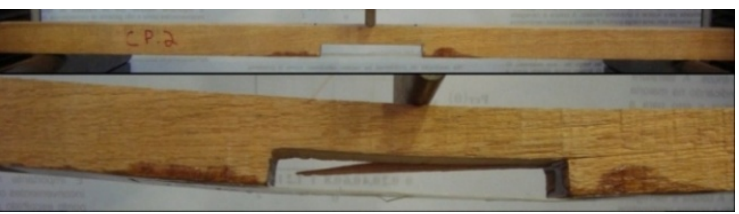

Figure 7. Specimen of Eucalyptus intact (top) and its disruption in the bending test (bottom)

Figure 8 illustrates the behaviour of the relationships between displacements and forces applied in the specimens obtained during the bending tests for the eight experimental conditions.

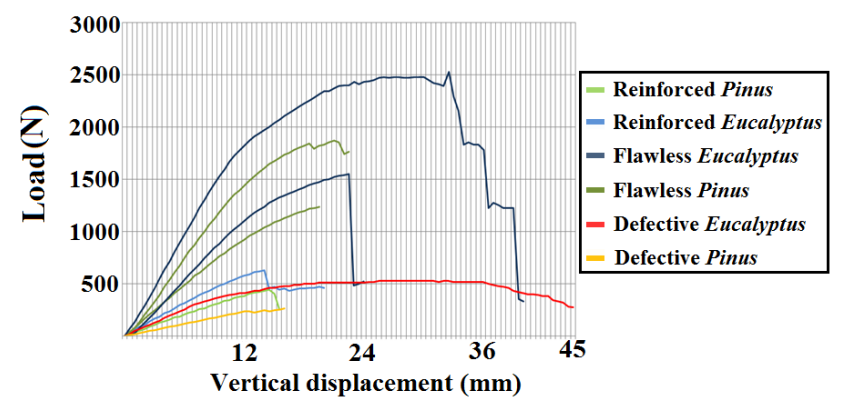

Figure 8. Results obtained in the bending test
From Figure 8 it is noted that the intact samples shows the maximu $m$ force $\left(\mathrm{F}_{\mathrm{MAX}}\right)$ higher than the strengthened, which in turn was superior to those at the specimens with defects.

It is also noted that Pinus support a load lower than the Eucalyptus in all conditions tested, but can also be seen in Table 1.

Table 1. Maximum load achieved in bending tests.

\begin{tabular}{c|c}
\hline Expe rimental Con ditions & $\mathbf{F}_{\mathbf{M A X}} \mathbf{( N )}$ \\
\hline \multirow{2}{*}{ Intact Pinus } & 1235.64 \\
\cline { 2 - 2 } & 1873.07 \\
\hline Flawless Pinus & 264.78 \\
\hline Reinforced Pinus & 441.30 \\
\hline \multirow{2}{*}{ Intact Eucalyptus } & 1549.45 \\
\cline { 2 - 2 } & 2530.12 \\
\hline Flawless Eucalyptus & 529.56 \\
\hline Reinforced Eucalyptus & 627.63 \\
\hline
\end{tabular}

The cracks in Pinus provided an average drop in maximum load in relation to intact timber about $82.96 \%$, while the reinforcement was able to increase the maximum load supported by $66.66 \%$ compared to flawless Pinus.Eucalyptus already cracked gave an average drop in maximum load in relation to intact timber about $74.04 \%$, while the reinforcement was able to increase the maximum load supported by $18.52 \%$ compared to flawless Eucalyptus.Given the above, it appears that when the timber is not enhanced fracture during the imposition of charges, the strengthening of the composite material has become more efficient.

Table 2 shows the individual values of the modulus of elasticity in bending $\left(E_{m}\right)$ and flexural strength modulus $\left(f_{m}\right)$ obtained for the intact Pinus elliiottiiand Eucalyptus grandis timber.

In Table 2, the Eucalyptushad a higher modulus of elasticity and flexural strength modulus that Pinus timber.

Table 2. Mechanical properties of the timber obtained by the static three points bending test

\begin{tabular}{c|c|c|c}
\cline { 2 - 4 } \multicolumn{2}{c|}{$\boldsymbol{F}_{\boldsymbol{M A X}}(\mathbf{N})$} & $\boldsymbol{f}_{\boldsymbol{m}}(\mathbf{M P a})$ & $\boldsymbol{E}_{\boldsymbol{m}}(\mathbf{M P a})$ \\
\hline \multirow{2}{*}{ Pinus } & 1235.64 & 6.17 & 8250 \\
\cline { 2 - 4 } & 1873.07 & 9.35 & 13544 \\
\hline \multirow{2}{*}{ Eucalyptus } & 1549.45 & 7.73 & 10428 \\
\cline { 2 - 4 } & 2530.12 & 12.63 & 17041 \\
\hline
\end{tabular}

\section{Conclusions}

Currently, researches are being directed to the production of laminates for structural reinforcement and low cost. These factors are affected by material selection, environmental conditions of rolling, the characteristics of the tooling and manufacturing methodology.

After a few tests on the materials presented in this work, we can conclude that the flawless specimens had a considerable reduction of its resistance to bending in relation to the intact timber. The addition of natural fiber reinforcement allowed reasonable increase in the flexural 
strength modulus of the flawless timber.

In future studies, we intend to evaluate other bonding areas, new timber species and the variation in the number of layers used in the preparation of the composite.

\section{REFERENCES}

[1] H., Cruz; J., Custodio,; J., Nascimento; M., Empis, "Execução e Controle de qualidade da reparação de estruturas de madeira com colas epoxídicas e FRPS", $1^{\circ}$ Congresso Ibérico Americano sobre a Madeira na construção. CIMAD, 2004.

[2] J. Cunha; D. A. Jr., Souza, “Avaliação estrutural de peças de madeira reforçadas com fibras de carbono". Revista Engenharia Civil, $\mathrm{N}^{\circ} 20$. Universidade Federal de Uberlândia, Uberlândia - MG, 2004.

[3] R. F., Carvalho, "Compósitos de fibras de sisal para uso em reforço de estruturas de madeira". Tese de doutorado em Ciência e Engenharia de Materiais. Escola de Engenharia de São Carlos, Universidade de São Paulo, São Carlos - SP, 2005.

[4] A. Borri; M. Corradi; A. Grazini, "A method for flexural reinforcement of old Wood beams with CFRP materials". Reinforced Plastics. Perugia, Italy. Vol. 36, pp. 143-153, March, 2005.

[5] L. J., Jankowski; J., Jasien; T. P., Nowak, "Experimental assessment of CFRP reinforced wooden beams by four point bending testes and photo elastic coating technique", Materials and Structures. Vol. 43,pp. 141-150, 2010.

[6] A. L., Chistoforo; T. H., Panzera; J. N. Brito; P. C.M, Lamim; L. C., Brandao, "Avaliação numérica do emprego de uma blenda cerâmica polimérica como reforço em vigas de madeira". XI Congresso Nacional de Engenharia Mecânica, Metalúrgica e Industrial de Porto Alegre - RS. 03 a 05 de agosto de 2011 .

[7] G., Mohamad; J.,Accordi; L. E., Roca, “Avaliação da associação de compósito de fibra de vidro e carbono no reforço de madeira de Eucalyptus in natura e autoclavada". Curso de Engenharia Civil, Campus Alegrete, UNICAMPA, Universidade Federal do Pampa. Matéria (Rio de Janeiro) v. 16, n.1, 2011.

[8] L. J. Silva; T. H., Panzera; V. R. V, Silva; A. L, Christoforo, "Investigação das Propriedades Mecânicas de Compósitos Poliméricos de Fibra de Bananeira através do Método de Planejamento Fatorial de Experimentos". Ciência e tecnologia dos materiais, v. 23, p. 10-14, 2011.

[9] J. Kuruvilla, R. D. F. Toledo, J. Beena, T. Sabu, L. H. Carvalho "A reviewon sisal fiber reinforced polymer composites". Revista Brasileira de Engenharia Agrícola e A mbiental, v.3, n.3, p.367-379, 1999.
[10] X. Lu, M. Q. Zhang, M. Z. Rong, D. L. Yue, G. C. Yang, "The preparation of self-reinforced sisal fiber composites". Poly mers \& Poly mer Composites, Vol. 12, $\mathrm{n}^{\mathrm{o}}$. 4, p. 297-308, 2004.

[11] S. Taj, M. A. Munawar, S. U. Khan, "Natural fiber-re inforced polymer composites". Proc. Pakistan Acad. Sci. vol. 44, no 2, p. 129-144, 2007.

[12] J. C. K. Verney, M. F. S. Lima, D. M. Lenz, "Properties of SBS and sisal fiber composites: ecological material for shoe manufacturing". Materials Research. vol.11 $\mathrm{n}^{\mathrm{o}} 4$, p. 447-451, 2008.

[13] Kalia S., Kaith B.S, Kaur I., "Pretreatments of natural fibers and their application as reinforcing material in polymer composites - a review". Polymer Engine ering \& Science, Vol. $49, \mathrm{n}^{\mathrm{0}} 7, \mathrm{p} .1253-1272,2009$.

[14] T. H. Panzera; L. J. Silva, V. R. V. Silva, A. L. Christoforo, F. Scarpa, "Hybrid polymeric composites reinforced with sisal fibres and silica microparticles". Composites Part B, Engineering, 2012.

[15] A., O'donnell; M., Dweib; R., Wool, "Natural fiber composites with plant oil-based resin", Composites Science and Technology, vol. 64, pp. 1135-1145, 2004.

[16] K. L., Pickering; G. W., Beckermann; S. N., Alam; J., N., Foreman "Optimising industrial hemp fibre for composites", Composites: Part A vol. 38 pp. 461-468, 2007.

[17] A., T. Ticoalu, F. Aravinthan, F.Cardona, "A review of current development in natural fiber composites for structural and infrastructure applications". Southern Region Engineering Conference, Toowoomba, Australia, 2010.

[18] R. D. S. G., Campilho; M. D., Banea; A. M., Pinto; L. F. M., Silva, "Reparação de vigas de madeira com laminados de Compósitode carbono-epóxido". EncontroNacional de Materiais e EstruturasCompósitas, Porto, Portugal, 2010.

[19] Associação Brasileira de Normas Técnicas (ABNT). "Projeto de Estruturas de Madeira”. NBR 7190, Rio de Janeiro, 1997.

[20] A. L., Christoforo; T. H., Panzera; F. B., Batista; P. H. R., Borges; F. A. L., "Numerical evaluation of the modulus of longitudinal elasticity in structural round timber elements of the Eucalyptus genus". EngenhariaAgrícola - Jaboticabal, v. 31, p. 1007-1014, 2011.

[21] A. L., Christoforo; T. H., Panzera; F. B., Batista; P. H. R., Borges; F. A. L., Rocco; C. F., Franco, "The position effect of structural Eucalyptus round timber on the flexural modulus of elasticity". EngenhariaAgrícola - Jaboticabal, v. 31, p. 1219-1225, 2011.

[22] A. L. Christoforo; A. R. V.,Wolenski; T. H., Panzera; F. B. Batista; P. C. M., Lamim Filho, "Verificação da Validade sobre a Hipótese de Pequenos Deslocamentos em Vigas de Madeira do Gênero Eucalyptus". Revista Brasileira de Biometria, v. 29, p. 11-25, 2011 